\title{
Banff klasifikacija patohistologije bubrežnih presadaka
}

\section{The Banff classification of renal allograft pathology}

\author{
Gordana Đorđevićc ${ }^{1 *}$, Danica Galešić Ljubanović
}

${ }^{1}$ Klinički zavod za patologiju i citologiju, KBC Rijeka i Medicinski fakultet Sveučilišta u Rijeci, Rijeka, Hrvatska

${ }^{2}$ Odjel za nefropatologiju i elektronsku mikroskopiju, Klinički zavod za patologiju i citologiju, KB Dubrava i Zavod za patologiju, Medicinski fakultet Sveučilišta u Zagrebu, Zagreb, Hrvatska

\author{
*Dopisni autor: \\ Izv. prof. dr. sc. Gordana Đorđević, dr. med. \\ Klinički zavod za patologiju i citologiju, \\ Klinički bolnički centar Rijeka, \\ Krešimirova 42, 51000 Rijeka \\ E-mail: gordana.dordevic@medri.uniri.hr
}

SAŽETAK. Do ranih 1990-ih nije postojala standardizirana međunarodna klasifikacija biopsija bubrežnih presadaka. To je rezultiralo značajnom heterogenošću patohistoloških nalaza između različitih centara. Skupina nefropatologa, nefrologa i transplantacijskih kirurga napravila je u Banffu (Alberta, Kanada) 1991. prvi klasifikacijski sustav histoloških promjena u transplantiranom bubregu koji je pružio smjernice za patohistološku i kliničku dijagnozu te omogućio usporedbu između istraživačkih i kliničkih studija za dijagnozu, liječenje i ishod transplantiranih bubrega. Bio je to početak danas općeprihvaćene Banff klasifikacije. Navedeni eksperti nastavili su se sastajati svakih nekoliko godina te su Banff klasifikaciju prilagođavali i mijenjali u skladu s najnovijim spoznajama. Cilj rada je prikazati Banff klasifikaciju bubrežnih presadaka kroz njenu povijest od početaka do posljednjeg izvještaja. Dijagnostička procjena patologije bubrežnih presadaka uvelike je poboljšana, kvantificirana i klinički dokazana, ali mnoga pitanja još treba proučiti. Trenutne preporuke se i dalje klinički vrednuju, a izvještaj o tome i nove teme bit će raspravljeni na jubilarnom sastanku o tridesetoj godišnjici Banff susreta 2021. godine u gradu Banffu iz kojega je klasifikacija i potekla.

Ključne riječi: Banff klasifikacija; odbacivanje presatka; transplantacija bubrega

Abstract. Until the early 1990s, there was no standardized international classification of the renal allograft biopsies resulting in significant heterogeneity of biopsy findings between different centres. A group of nephropathologists, nephrologists and surgeons developed in Banff (Alberta, Canada) in 1991 the first classification system (the so-called Banff classification) which provided guidelines for the pathohistological and clinical diagnosis and enabled meaningful comparisons between research and clinical studies for diagnosis, treatment and outcome of the renal allograft pathology. The aim of this article is to present the Banff classification through its history from the beginnings to the recent reports. The diagnostic assessment of the kidney allograft pathology has been greatly improved, quantified, and clinically proven but many issues remain to be studied. Current recommendations are further clinically validated and the report and new topics will be discussed at the jubilee meeting in 2021 in Banff, the city from which the Banff classification originates.

Key words: Banff classification; kidney transplantation; transplant rejection

http://hrcak.srce.hr/medicina 


\section{UVOD}

Do ranih 1990-ih nije postojala standardizirana međunarodna klasifikacija biopsija bubrežnih presadaka. To je rezultiralo značajnom heterogenošću patohistoloških nalaza između različitih centara. Skupina izrazito posvećenih i motiviranih nefropatologa, nefrologa i transplantacijskih kirurga razvila je u Banffu (Alberta, Kanada) 1991. godine klasifikaciju za patohistološke promjene u biopsijama bubrežnih transplantata. Ova inicijativa bila je nadahnuta tadašnjim razvojem sustava za postizanje konsenzusa za dijagnozu odbacivanja srčanih presadaka dr. Margaret Billingham, koja je bila ključna sudionica prvog sastanka o patologiji transplantacije ${ }^{1}$.

Navedena Banff klasifikacija bila je prvi klasifikacijski sustav koji je dao smjernice za patohistološku i kliničku dijagnozu te omogućio smislenu usporedbu između istraživačkih i kliničkih studija za dijagnozu, liječenje i ishod transplantacije bubrega. Klasifikacija je nakon 1991. godine bila višestruko revidirana svakih nekoliko godina. Revizije su se te- meljile na znanstvenim istraživanjima pretočenim u dokaze na temelju kojih je klasifikacija dodatno razrađivana, nadopunjavana i usuglašavana na sastancima međunarodnih stručnjaka koji se redovito održavaju svake dvije godine pod nazivom Banff konferencije. Kao rezultat takvih 15 međunarodnih konferencija publicirano je 11 preglednih članaka s nadopunama i pojašnjenjima Banff klasifikacije patologije bubrežnih presadaka, a sama klasifikacija postala je prevladavajući sustav koji se koristi širom svijeta $^{2,3}$. Tablica 1 prikazuje dijagnostičke kategorije za interpretaciju biopsija bubrežnog presatka

Prva Banff klasifikacija objavljena je 1993. godine, a uključivala je analizu intersticija, tubula, krvnih žila i glomerula. Histopatološki nalaz biopsije bubrežnog presatka podijeljen je kao normalan nalaz, hiperakutno odbacivanje, granične promjene, akutno odbacivanje, kronična nefropatija presatka te promjene koje nisu posljedice odbacivanja.

Tablica 1. Dijagnostičke kategorije za interpretaciju biopsija bubrežnog presatka prema Banff klasifikaciji iz 1991. godine

1. Normalan nalaz

2. Hiperakutno odbacivanje

- odbacivanje uzrokovano humoralnim odgovorom karakterizirano akumulacijom polimorfonukleara u glomerulima i peritubularnim kapilarama jedan sat nakon transplantacije s posljedičnim oštećenjem endotela i kapilarnom trombozom

3. Granične promjene ( veoma blago akutno odbacivanje)

- bez intimalnog arteritisa s blagim ili umjerenim tubulitisom (> 4 mononuklearne upalne stanice / poprečnom presjeku tubula ili na 10 tubularnih stanica)

4. Akutno odbacivanje

- I. stupanj, blago akutno odbacivanje:

značajni intersticijski upalni infiltrat sa zahvaćanjem $>25$ \% površine cilindra i žarištima umjerenog tubulitisa ( $>4$ mononuklearne upalne stanice / poprečnom presjeku tubula ili na 10 tubularnih stanica)

- II. stupanj, umjereno akutno odbacivanje:

(A) značajni intersticijski upalni infiltrat sa zahvaćanjem > $25 \%$ površine cilindra i žarištima teškog tubulitisa ( $>10$ mononuklearne upalne stanice / poprečnom presjeku tubula) i/ili (B) blagi ili umjereni intimalni arteritis

- III. stupanj, teško akutno odbacivanje:

teški intimalni arteritis i/ili transmuralni arteritis s fibrinoidnom promjenom i nekrozom glatkih mišićnih stanica medije. Svježi fokalni infarkti parenhima i intersticijska krvarenje bez drugih jasnih uzroka indirektni su znaci odbacivanja III. stupnja

5. Kronična nefropatija presatka

(Glomerularne ili vaskularne lezije kroničnog tipa, novonastalo fibrointimalno zadebljanje stijenke arterija upućuje na prisustvo kroničnog odbacivanja)

- I. stupanj, blago kronično odbacivanje karakterizirano je blagom intersticijskom fibrozom i tubularnom atrofijom

- II. stupanj, umjereno kronično odbacivanje: karakterizirano je umjerenom intersticijskom fibrozom i tubularnom atrofijom

- III. stupanj, teško kronično odbacivanje: karakterizirano je teškom intersticijskom fibrozom i tubularnom atrofijom

6. Druge promjene (različite etiologije)

Izrazi blago, umjereno ili teško opisni su izrazi potkrijepljeni numeričkim određivanjem količine $(0 ; 1 ; 2 ; 3)$ upalnog infiltrata, fibroze, atrofije tubula, opsega krvne žile i/ili \% površine zahvaćenog parenhima (cilindra) (prilagođeno prema referenci br. 3 ). 
prema prvoj Banff klasifikaciji iz 1991., koja je objavljena 1993. godine ${ }^{3}$.

Kao što je već spomenuto, cilj prve Banff klasifikacije bio je standardizirati histopatološke nalaze, terminologiju i dijagnozu biopsija bubrežnih presadaka. Adekvatnost uzorka je bila zadovoljena kod prisustva $>7$ glomerula s najmanje jednom arterijom. Značajke prve klasifikacije su uvođenje graničnih (engl. borderline) kategorija, kronične transplantacijske nefropatije te stupnjevanje „akutnog odbacivanja“ kao blagog, umjerenog i teškog. Banff klasifikacija je također uvela sustav numeričkog ocjenjivanja promjena za svaki histološki dio bubrežnog parenhima - intersticij (i), tubule (t), krvne žile (v) i glomerule (g) kao: 0 - nema patoloških promjena, 1 - blage, 2 - umjerene i 3 - teške patološke promjene. Patohistološki nalaz biopsija bubrežnih presadaka konačno je razvrstan u kategorije kao: normalan nalaz, hiperakutno odbacivanje, granične promjene, akutno odbacivanje, kronična nefropatija presatka te promjene koje nisu posljedice odbacivanja (tablica 1).

Kronična nefropatija presatka je izraz i klasifikacijska shema uvedena kao patohistološka poveznica s kroničnom disfunkcijom presatka. Uzroci kronične nefropatije presatka mogu biti, uz kronično odbacivanje, promjene koje nastaju zbog toksičnosti kalcineurinskih inhibitora (npr. ciklosporina), hipertenzije ili kronične infekcije. Značajke koje sugeriraju kronično odbacivanje su kronična transplantacijska glomerulopatija i vaskulopatija koje su se također počele stupnjevati po težini od blagih do teških ${ }^{4}$.

\section{KOOPERATIVNA KLINIČKA ISPITIVANJA} U TRANSPLANTACIJI

Na temelju Banff klasifikacije je 1997. godine u centrima koji sudjeluju u kooperativnim kliničkim ispitivanjima u transplantaciji (CCTT od engl. Cooperative Clinical Trials in Transplantation), a pod pokroviteljstvom Nacionalnih instituta za zdravstvo Sjedinjenih Američkih Država, razvijen sustav bodovanja za dijagnozu akutnog odbacivanja bubrega (CCTT klasifikacija). Jednostavniji CCTT sustav je zamijenio „stupnjeve odbacivanja” u Banff klasifikaciji „vrstama odbacivanja“. Granično odbacivanje se izgubilo iz klasifikacije, a kriteriji za tu kategoriju postali su prema CCTT klasifikaciji značajke odbacivanja tipa I koje je definirano mononuklearnim intersticijskim upalnim infiltratom (> $5 \%$ parenhima) i tubulitisom. Ovaj sustav prepoznao je važnost vaskulitisa per se zbog odabira i odgovora na terapiju te preživljavanja presatka. Odbacivanje tipa II po CCTT klasifikaciji definirano je arterijskim ili arteriolarnim endotelitisom, a tip III fibrinoidnom nekrozom ili transmuralnom upalom $^{5}$. Ti su kriteriji naknadno ugrađeni u Banff klasifikaciju iz 1997. godine. Trenutno se CCTT klasifikacija samostalno više ne koristi.

U Banff klasifikaciji iz 1997. godine uvedene su važne promjene koje uključuju adekvatnost uzorka od 2 cilindra kore bubrega s 10 i više glomerula te najmanje dvije arterije. Kategorija hiperakutnog odbacivanja preimenovana je $u$ antitijelima posredovano odbacivanje (ABMR - od engl. Antibody-mediated Rejection) i podijeljena je u dva stupnja: hiperakutno i ubrzano akutno odbacivanje. Prisustvo intimalnog arteritisa definirano je kao akutno odbacivanje tipa II, dok je teški tubulitis bez arteritisa preklasificiran $u$ akutno odbacivanje tip IB. Također je prepoznato da se ABMR može javiti istodobno $s$ akutnim staničnim odbacivanjem ${ }^{4}$.

\section{VAŽNOST C4D KOMPONENTE KOMPLEMENTA}

Publikacija rezultata Banff sastanka iz 2001. koja je objavljena 2003. godine istaknula je povezanost taloženja C4d komponente komplementa (difuzno pozitivna reakcija na stijenkama peritubularnih kapilara uz tubularnu ekspresiju HLADR) s kraćim preživljenjem bubrežnog presatka. Stoga je imunoekspresija C4d na peritubularnim kapilarama (ptc) prihvaćena kao marker ABMR s detaljnom patološkom klasifikacijom kako slijedi:

- Stupanj I: C4d +, nalik akutnoj tubularnoj nekrozi (ATN) s minimalnom upalom;

- Stupanj II: C4d +, kapilarna marginacija i/ili tromboza;

- Stupanj III: C4d +, transmuralni arteritis (v3).

Prethodna kategorija akutnog odbacivanja preimenovana je u akutno/aktivno stanično odbacivanje. $U$ terapiji je upotreba plazmafereze i intravenskog imunoglobulina povezana s dobrim ishodom liječenja humoralnog odbacivanja, a na popis novih metoda liječenja uvrštena je $\mathrm{i}$ antiCD-20 terapija ${ }^{6,7}$. 
Osma Banff konferencija održana je u srpnju 2005. godine, a njeni glavni rezultati su objavljeni u publikaciji Soleza i suradnika 2007. godine. Ova revidirana Banff klasifikacija temeljila se na patofiziologiji reakcije odbacivanja prema kojoj odbacivanje može biti posredovano antitijelima (ABMR) i posredovano T stanicama (TCMR - od engl. T-cell-mediated rejection). Svako od ovih odbacivanja može biti akutno ili kronično. Kronična nefropatija presatka je kao entitet eliminirana iz klasifikacije zbog nekonzistentnosti većinom vezane uz etiologiju ${ }^{8}$. Pojam kronične nefropatije presatka zamijenjen je kategorijom intersticijska fibroza i tubularna atrofija (IFTA) koja se koristi samo onda kada nije poznata etiologija kroničnih promjena, a ocjenjuje se kao blaga, umjerena $\mathrm{i}$ teška. Posebno treba opisati kronične promjene vezane uz odbacivanje presatka (kronično antitijelima ili stanicama posredovano odbacivanje) ili terapiju odbacivanja (toksičnost kalcineurinskih inhibitora). Također treba uzeti u obzir druge specifične uzroke kroničnih promjena u presatku, kao što su oštećenja u sklopu hipertenzije, povrat primarne bolesti, opstrukcije, bakterijske i virusne infekcije (npr. BK virus). Neke od njih mogu biti prisutne u trenutku presađivanja, što utvrđujemo nultom biopsijom. Tablica 2 prikazuje uzroke (stanja) koji mogu dovesti do intersticijske fibroze i tubularne atrofije te uznapredovale skleroze glomerula i stijenki krvnih žila, što uzrokuje kroničnu disfunkciju presatka?.
Tablica 2. Stanja koja uzrokuju kroničnu disfunkciju presatka

Stanja koja dovode do kronične disfunkcije presatka koja se mogu potvrditi biopsijom bubrega

- kronično odbacivanje posredovano protutijelima

- kronično odbacivanje posredovano stanicama

- toksičnost kalcineurinskih inhibitora

- hipertenzivna oštećenja

- BK virusna nefropatija

- bakterijske infekcije

- povrat primarne bolesti

(prilagođeno prema referenci br. 9)

\section{POSTUPNIK ISTRAŽIVANJA}

Tijekom odbacivanja dolazi do aktivacije određenih gena. Proučavanje transkripcijskog profila tih gena vjerojatno može unaprijediti dijagnostiku promjena u bubrežnom transplantatu, naročito u području „graničnog odbacivanja“. Stoga se očekuje da će buduće Banff klasifikacije integrirati u postupnik postavljanja dijagnoze i molekularne parametre ${ }^{10-12}$. Na tom tragu formirane su Banff radne grupe (BWG-a od engl. Banff Working Group), kao npr. za trombotičku mikroangiopatiju, povrat primarne glomerularne bolesti i dijagnostičku elektronsku mikroskopiju. Jedna od radnih skupina izrađuje i vrednuje složeni sustav bodovanja integrirajući patohistološki nalaz s drugim relevantnim biomarkerima za predviđanje dugoročnog preživljavanja presatka. Sustav služi kao

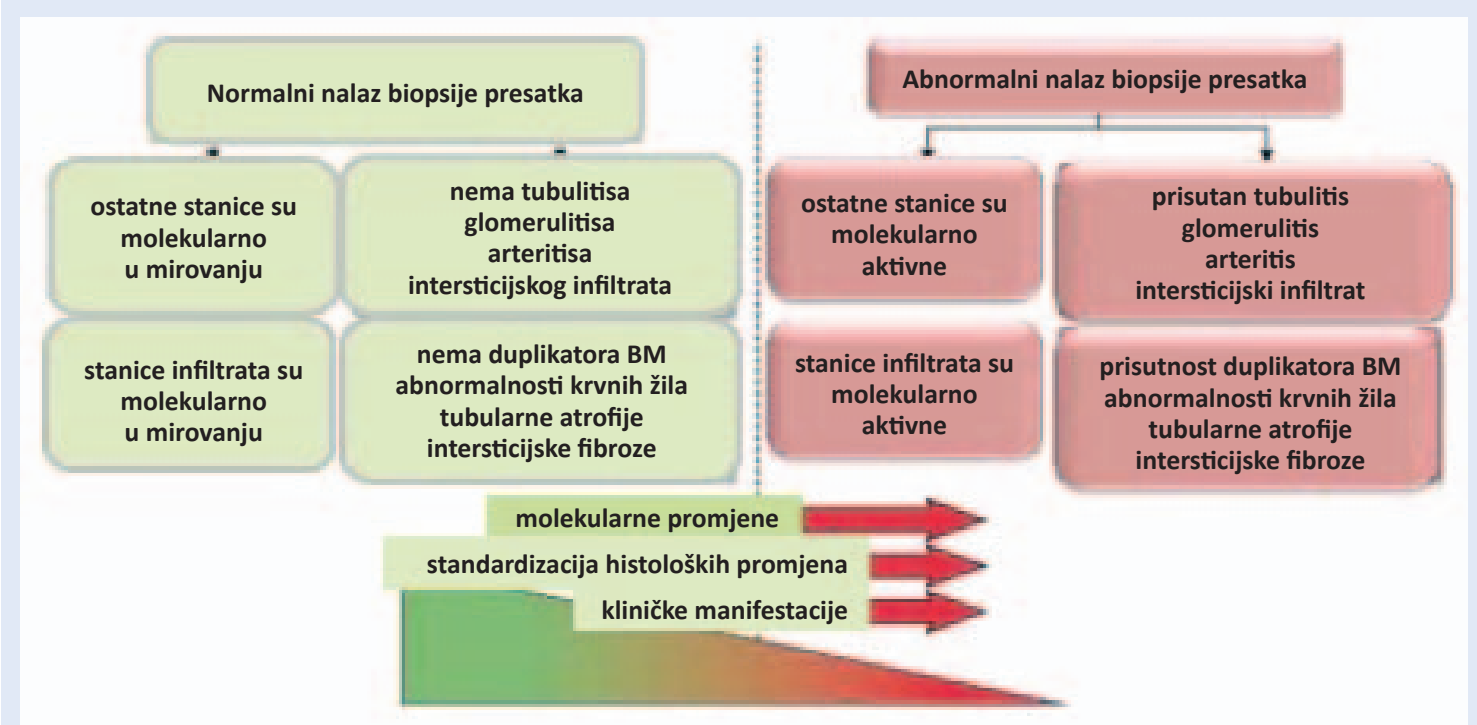

Slika 1. Postupnik daljnjih usavršavanja Banff klasifikacije (prilagođeno prema referenci 14). 
potencijalno polazište za klinička ispitivanja sljedeće generacije na tom području ${ }^{13}$.

Zaključci novijih Banff konferencija odnose se na reviziju C4d negativnog nalaza u sklopu odbacivanja posredovanog protutijelima, povezanost testova za donor-specifična protutijela (DSA) i patohistoloških nalaza te upotrebu genskih testova uz razvoj klasifikacije njihovih rezultata, određivanje ključnih gena kao dijagnostičkih surogata ili suplemenata postojećim dijagnostičkim kriterijima, što zahtijeva dugotrajnu validaciju. Cilj je tije-

Sljedeće Banff konferencije bavile su se ulogom C4d komponente komplementa, povezanošću donor specifičnih protutijela s histopatološkim nalazom te uporabom genskih testova. Osnovni cilj je korištenje i integracija novijih dijagnostičkih postupaka s naglaskom na njihovu kliničku primjenjivost i značajnost.

kom integracije napretka u histološkim, serološkim i molekularnim dijagnostičkim tehnikama, temeljem konsenzusa, stvoriti sustav izvješćivanja koji nudi preciznost, točnu rutinsku dijagnostiku i primjenjivost u budućim kliničkim ispitivanjima. Slika 1 prikazuje postupnik daljnjih nastojanja u cilju razvoja Banff klasifikacije i njezine kliničke primjenjivosti ${ }^{14}$.

\section{MIKROVASKULARNA UPALA}

Banff klasifikacija iz 2013. godine ukazala je na dijagnostičku važnost $\mathrm{Cd} 4$ pozitivnog nalaza u stijenkama peritubularnih kapilara koji i dalje ostaje jedan od glavnih čimbenika za dijagnozu ABMR, međutim, C4d negativno ABMR uvodi se kao dijagnoza ako postoji glomerulitis i značajniji peritubularni kapilaritis. Dijagnostički kriteriji ABMR-a od tada su se značajno promijenili. Jedna od najvažnijih stavki u reviziji Banff klasifikacije bila je usvajanje mikrovaskulaturnih upalnih promjena (MVI od engl. microvascular inflammation) kao imunopatološkog dokaza za ABMR čak i u slučajevima negativnim za $C 4 d^{15}$. Podaci su pokazali da je MVI usko povezan s DSA-om i bolje predviđa ishod preživljavanja presatka nego pozitivnost C4d ${ }^{16}$. Temeljem tih saznanja, Banff klasifikacija iz 2013. detaljno je izmijenila dijagnostičke kriterije ABMR-a, a Banff klasifikacija iz 2017. ih je dopu- nila. Trenutno su potrebne tri kategorije dokaza za dijagnozu ABMR-a. Prvo, za aktivni ABMR histološki dokazi uključuju $\mathrm{MVI}$, intimalni ili transmuralni arteritis, akutnu trombotičku mikroangiopatiju i akutno tubularno oštećenje. Kod kroničnog aktivnog ABMR-a histološki se nalazi transplantacijska glomerulopatija, višeslojna bazalna membrana peritubularnih kapilara i fibroza intime arterija. Druga skupina dokaza su nalaz svježe interakcije antitijela s endotelom u vidu C4d linearnog pozitiviteta u peritubularnim kapilarama i/ili MVI odnosno ekspresija gena povezanih s ABMR-a. Treća kategorija potrebna za finalnu dijagnozu ABMR-a je prisustvo DSA-a u serumu ${ }^{17}$.

\section{BANFF KLASIFIKACIJA IZ 2019.}

Posljednja, XV. Banff konferencija održana 2019. godine u Pittsburghu (SAD) usredotočila se na ažuriranje klasifikacije, napredak Banff radnih skupina i standardizaciju molekularne dijagnostike. Cilj je bio razjasniti dijagnostičke kriterije za ABMR i kronično aktivno TCMR radi usklađivanja patološke dijagnoze i posljedične terapijske strategije. Postignut je i dogovor za dijagnozu graničnog TCMR-a ${ }^{18}$. Ova klasifikacija detaljno je razradila kriterije za 5 kategorija promjena:

- kategorija I: normalan nalaz;

- kategorija II: antitijelima posredovano odbacivanje transplantata (aktivni ABMR, kronični aktivni $A B M R$, kronični inaktivni $A B M R$ );

- kategorija III: granično (sumnja na) odbacivanje posredovano stanicama (TCMR);

- kategorija IV: odbacivanje posredovano stanicama (akutni i kronično aktivni TCMR);

- kategorija V: polioma virusna nefropatija.

Dijagnoza aktivnog i kroničnog ABMR-a zahtijeva prisutnost morfoloških, imunohistoloških i seroloških dokaza. Morfološki nalaz aktivnih i kroničnih promjena posebno je definiran $s$ tim da aktivne promjene mogu koegzistirati u kroničnom aktivnom ABMR-u. Suprotno tome, imunohistološki i serološki pokazatelji su isti za aktivni i kronični ABMR. Imunohistološki se dokazuje C4d linearni pozitivitet u peritubularnim kapilarama, MVI te povećana ekspresija transkripata gena indikativnih za ozljedu endotela. Serološki se i u akutnim i kroničnim ABMR-om nalazima DSA-a ${ }^{19}$. U slučajevima odsustva morfoloških znakova ak- 
tivne upale, negativne reakcije za C4d ili odsutnosti DSA-a u serumu nove smjernice u klasifikaciji uključuju povećanu ekspresiju transkripata/klasifikatora gena povezanih s ABMR-om kao alternativu pozitivnoj reakciji na $\mathrm{C} 4 \mathrm{~d}^{17}$.

Dijagnostički kriteriji za prepoznavanje akutnog TCMR stvoreni su na temelju morfoloških promjena u tubulointersticiju i nisu se značajnije mijenjali od Banff klasifikacije iz 1991. godine. Već je spomenuto da se ocjenjuje opsežnosti upalnog infiltrata u intersticiju, prisustvo upalnih stanica između epitelnih stanica neatrofičnih tubula (tubulitis) te upala stijenki krvnih žila. Kriteriji za kronično aktivno TCMR ažurirani su u Banff klasifikaciji iz 2017. godine. Za dijagnozu je potrebna intersticijska upala i tubulitis u područjima $s$ atrofičnim tubulima i intersticijskom fibrozom, kao i u neatrofičnim tubulima (slika 2) 20,21.

Kao petu kategoriju, najnovija Banff klasifikacija navodi BK virusnu nefropatiju koja, kao komplikacija transplantacije bubrega, u 2 \% transplantirane populacije predstavlja velik rizik za gubitak presatka. Budući da nema učinkovite terapije, molekularno praćenje u krvi i urinu te biopsija bubrega mogu poboljšati preživljenje presatka uz korekciju imunosupresivne terapije kod prepoznate infekcije ${ }^{22}$. Slika 3 prikazuje imunohistokemijski dokaz BK infekcije. Klasifikacija Banff radne skupine za poliomavirus nefropatiju dijeli BK nefropatiju u 3 razreda, a za prognozu se oslanja prvenstveno na količinu virusa $u$ tkivu bubrega $i$ stupanj intersticijske fibroze ne uzimajući u obzir količinu upale ${ }^{23}$.

Na Banff konferenciji 2019. raspravljalo se i o mogućnostima umjetne inteligencije i potencijalu za upotrebu algoritama strojnog učenja u dijagnozi i personaliziranoj terapiji u transplantatima solidnih organa, uključujući i bubreg ${ }^{18}$.

Zaključno, najnoviji međunarodni konsenzus o Banff klasifikaciji je u tijeku. Dijagnostička procjena patologije bubrežnog presatka je uvelike poboljšana, kvantificirana i klinički dokazana, ali mnoga pitanja još treba proučiti. Trenutne preporuke Banff klasifikacije se dalje klinički vrednuju, a izvještaji o tome i nove teme se ostavljaju za jubilarni sastanak o tridesetoj godišnjici Banff klasifikacije koji će se održati od 4. do 7. listopada 2021. u Banffu, gdje je sve i počelo.

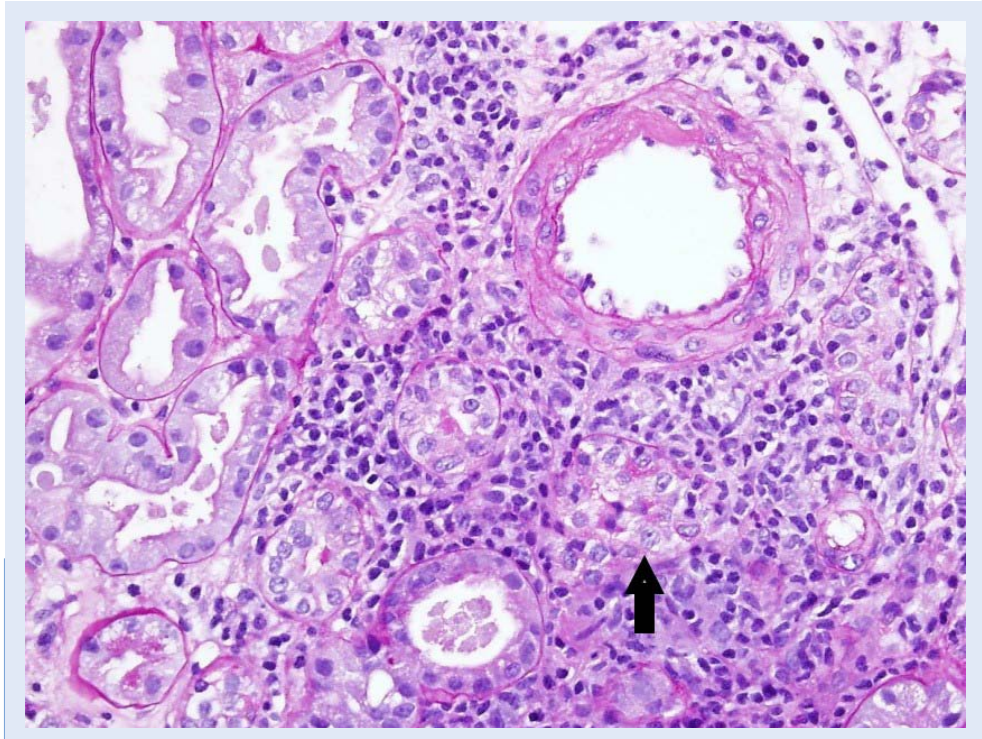

Slika 2. Mikrofotografija akutnog celularnog odbacivanja. Prisutan je gusti intersticijski upalni infiltrat uz tubulitis (označen strjelicom). (PAS, originalno povećanje $200 \mathrm{x}$; iz arhive fotografija Zavoda za patologiju Medicinskog fakulteta Rijeka).

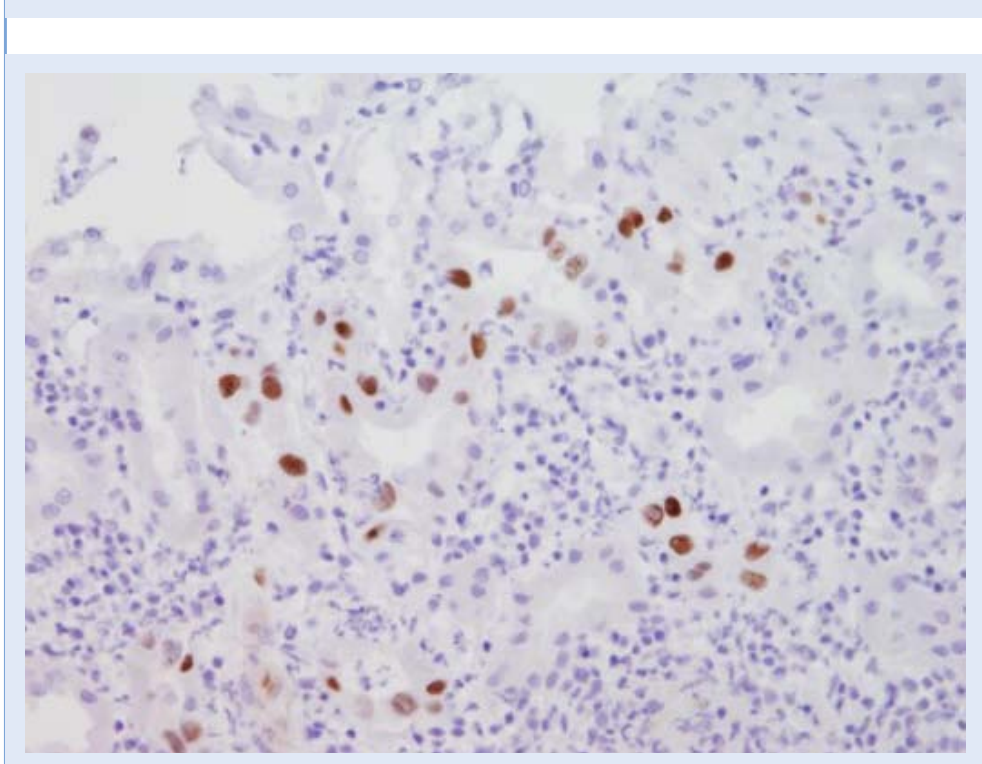

Slika 3. Mikrofotografija akutne upale izazvane BK infekcijom (imunohistokemijsko bojenje sa SV-40 dokazuje prisustvo virusa, pozitivno nuklearno obojenje, originalno povećanje 200 x; iz arhive fotografija Zavoda za patologiju Medicinskog fakulteta Rijeka).

Izjava o sukobu interesa: Autori izjavljuju da ne postoji sukob interesa.

\section{LITERATURA}

1. Pappas S. Margaret Billingham, Pioneer in Heart Transplant Pathology Dies at 78 [Internet]. Stanford Medicine News Centre. [cited 2020 September 01]. Available from:https://med.stanford.edu/news/all-news/2009/ $07 /)$.

2. Roufosse $C$, Simmonds $N$, Clahsen-van Groningen $M$, Haas M, Henriksen KJ, Horsfield C et al. MDA 2018 Refer- 
ence Guide to the Banff Classification of Renal Allograft Pathology. Transplantation 2018;102:1795-814.

3. Solez K, Axelsen RA, Benediktsson H, Burdick JF, Cohen $\mathrm{AH}$, Colvin RB et al. International standardization of criteria for the histologic diagnosis of renal allograft rejection: The Banff working classification of kidney transplant pathology. Kidney Int 1993;44:411-22.

4. Racusen LC, Solez K, Colvin RB, Bonsib SM, Castro MC, Cavallo $T$ et al. The Banff ' 97 working classification of renal allograft pathology. Kidney Int 1999;55:713-23.

5. Colvin RB, Cohen AH, Saiontz C, Bonsib S, Buick M, Burke $B$ et al. Evaluation of pathologic criteria for acute renal allograft rejection: Reproducibility, sensitivity, and clinical correlation. J Am Soc Nephrol 1997;8:1930-41.

6. Racusen LC, Colvin RB, Solez K, Mihatsch MJ, Halloran PF, Campbell PM et al. Antibody-mediated rejection criteria-an addition to the Banff ' 97 classification of renal allograft rejection. Am J Transplant 2003;3:706-14.

7. Mauiyyedi S, Pelle PD, Saidman S, Collins AB, Pascual M, Tolkoff-Rubin NE et al. Chronic humoral rejection: Identification of antibody-mediated chronic renal allograft rejection by C4d deposits in peritubular capillaries. J Am Soc Nephrol 2001;12:574-82.

8. Solez K, Colvin RB, Racusen LC, Sis B, Halloran PF, Birk PE et al. Banff '05 meeting report: Differential diagnosis of chronic allograft injury and elimination of chronic allograft nephropathy ('CAN'). Am J Transplant 2007;7:518-26.

9. Bhowmik DM, Dinda AK, Mahanta P, Agarwal SK. The evolution of the Banff classification schema for diagnosing renal allograft rejection and its implications for clinicians. Indian J Nephrol 2010;20:2-8.

10. Saint-Mezard P, Berthier $\mathrm{CC}$, Zhang $\mathrm{H}$, Hertig A, Kaiser $\mathrm{S}$, Schumacher $M$ et al. Analysis of independent microarray datasets of renal biopsies identifies a robust transcript signature of acute renal rejection. Transpl Int 2009;22:293-302.

11. Reeve J, Einecke G, Mengel M, Sis B, Kayser N, Kaplan B et al. Diagnosing rejection in renal transplants: A comparison of molecular and histopathology based approaches. Am J Transplant 2009;9:1802-10.

12. Mueller TF, Einecke $G$, Reeve J, Sis $B$, Mengel M, Jhangri GS et al. Microarray Analysis of Rejection in Human Kidney Transplants Using Pathogenesis-Based Transcript Sets. Am J Transplant 2007;7:2712-22.
13. Loupy $A$, Haas $M$, Solez $K$, Racusen L, Glotz D, Seron D et al. The Banff 2015 Kidney Meeting Report: Current Challenges in Rejection Classification and Prospects for Adopting Molecular Pathology. Am J Transplant 2017;17: 28-41.

14. Solez K, Racusen LC. Banff classification revisited. Kidney Int 2013;83:201-6.

15. Haas M, Sis B, Racusen LC, Solez K, Glotz D, Colvin RB et al. Banff 2013 Meeting Report: Inclusion of C4d-Negative Antibody-Mediated Rejection and Antibody-Associated Arterial Lesions. Am J Transplant 2014; 14:272-83.

16. Sook H, Deok J, Kimb G, Leec ST, Huhb KH, Seun Y et al. Clinical Significance of Revised Banff Criteria in the Diagnosis of Antibody-Mediated Rejection. Transplant Proc 2019:51;1488-9.

17. Haas M, Loupy A, Lefaucheur C. The Banff 2017 Kidney Meeting Report: revised diagnostic criteria for chronic active T cell-mediated rejection, antibody-mediated rejection, and prospects for integrative endpoints for nextgeneration clinical trials. Am J Transplant 2018:18; 293-307.

18. Loupy A, Haas M, Roufosse C, Naesens M, Adam B, Afrouzian M et al. The Banff 2019 Kidney Meeting Report (I): Updates on and clarification of criteria for T cell-and antibody-mediated rejection. Am J Transplant 2020;20: 2318-31.

19. Jeong HJ. Diagnosis of renal transplant rejection: Banff classification and beyond. Kidney Res Clin Pract 2020; 39(1):17-31.

20. Lefaucheur C, Viglietti D, Loupy A. Recognition of i-IF/TA as a component of the T cell-mediated rejection spectrum: unselected population approach vs random case selection. Am J Transplant 2018;18:771-2.

21. Nankivell BJ, Shingde M, Keung KL. The causes, significance and consequences of inflammatory fibrosis in kidney transplantation: the Banff i-IFTA lesion. Am J Transplant 2018;18:364-76.

22. Sawinski D, Trofe-Clark J, Clin J. BK Virus Nephropathy. Am Soc Nephrol 2018;13:1893-6.

23. Nickeleit V, Harsharan KS, Randhawa P. The Banff Working Group classification of definitive polyomavirus nephropathy: morphologic definitions and clinical correlations. J Am Soc Nephrol 2018;29:680-93. 